\title{
Salivary Characteristics of Diabetic Children
}

\author{
María Elena LÓPEZ1 \\ María Eugenia COLLOCA ${ }^{1}$ \\ Rafael Gustavo PÁEZ² \\ Judit Nora SCHALLMACH ${ }^{1}$ \\ Myriam Adriana KOSS $^{1}$ \\ Amalia CHERVONAGURA ${ }^{1}$
}

${ }^{1}$ Biologic Chemistry, Faculty of Dentistry, National University of Tucumán, San Miguel de Tucumán, Argentina
${ }^{2}$ Dentist

\begin{abstract}
Salivary components may suffer variations that can be detected by chemical determinations. The aim of this work was to determine physical and biochemical characteristics of the saliva of a group of diabetic children compared to those of a control group. Relation to oral health indices was also determined. Twenty diabetic children (3-15-years-old) and 21 control children (5-12-years-old) were included in this study. Total proteins, sugars and calcium were determined by colorimetric methods, and glucose, urea, $\alpha$-amylase and acid phosphatase by enzymatic methods. Our results demonstrated that acidic $\mathrm{pH}$, diminished salivary flow rate and excess foam are usually present in saliva of diabetic children. Total sugars, glucose, urea and total proteins were greater in diabetic patients than controls, while calcium values were decreased. These differences were confirmed by the discrimination test. Diabetic children have higher DMFT-dmft-deft and DMFS-dmfs-defs values compared to those of the control children despite their lower sugar intake. Some salivary components in addition to the diminished flow rate could be involved in the characterization of the oral health state of diabetic children.
\end{abstract}

Key Words: diabetes, children, saliva, oral health.

\section{INTRODUCTION}

Diabetic adults usually present altered salivary secretion that can cause disorders of hard and soft tissues of the mouth leading to cariostatic and gingival lesions $(1,2)$. However, in children there is no agreement in results that relate alterations of saliva chemical composition and oral health.

Karjalainen et al. (3) reported that in poorly controlled children and adolescents the DFS (decayed, filled surfaces) indices were significantly high and diabetes was associated with caries. However, the difference was not statistically significant if adjustments were made for age, age at the onset of diabetes and duration of disease. Diabetes also increases the risk of periodontitis, which appeared at earlier ages, and periodontal disease progression in adults (4).

It is well known that oral diseases can be caused by a number of factors of the oral cavity, with microorganisms being one of the main factors. However, diabetes may cause alterations of the salivary glands, which may contribute to an increased pathogenic bacteria number. A slow flow rate also affects the oral flora and alters saliva composition (5).

So far not many salivary parameters have been used to characterize illness states, probably because of the great variability they present in whole saliva (6). In the specific case of diabetes mellitus, there is no agreement on salivary parameters in children or adults. Many authors found higher glucose salivary levels in diabetic patients than in non-diabetics $(1,7)$ while Sharon et al. (8) did not report any difference. Other determinations such as immunoglobulins A and G, calcium and potassium are highly increased in diabetic saliva $(7,8)$.

The aim of this study was to describe physical, biochemical and dental characteristics of total saliva of 
a group of children with diabetes mellitus, and to determine the most indicative salivary parameters of this illness.

\section{MATERIAL AND METHODS}

\section{Population}

Twenty diabetic children (11 female and 9 male) admitted to the Endocrinology Service of the Niño Jesús Hospital, San Miguel de Tucumán, were selected. Their chronologic ages ranged from 3 to 15 years (mean \pm SD: $9.4 \pm 3.9$; female: $10.5 \pm 3.6$; male: $8.0 \pm 4.0$ ). On the day of the saliva collection none of them were in metabolic acidosis nor in a coma but several had been in these states before. All diabetic children were treated with human insulin. Although the study was started with more than 20 patients not all of them collaborated with saliva collection or the complete odontological examination. This incomplete data was similar to that considered, but was not included in the statistical analysis.

The control group consisted of 21 clinically healthy children ( 12 female and 9 male), between 5 and 12 years of age (mean \pm SD: $8.3 \pm 1.8$; female: $8.4 \pm 1.6$; male: $8.1 \pm 2.2$ ). For inclusion within this study, the control children met the following requirements: absence of active disease, no history of drug treatment or therapy within the previous months, and no history of diabetes

Both groups (diabetic and control) presented a Tanner puberal state between I and III, as reported by the same endocrinologist. Their diets were similar with respect to protein content, but control children were not limited in uptake of fat and carbohydrates. Socio-economical status was similar for both groups.

\section{Saliva Collection, Physical Characterization and Con- servation}

Total saliva collection from the diabetic and the control groups was performed in the morning, $8 \mathrm{~h}$ after eating, except for 3 patients with $2 \mathrm{~h}$ of fasting. Their results were not statistically different from the rest. Stress situations of the children prior to and during saliva collection were avoided.

Saliva (5 min production) was collected with a sterile syringe, avoiding contact with the epithelia. No stimulation or spitting was practiced. Saliva was placed into ice-chilled graded tubes and brought immediately to the laboratory.

Flow rate was defined as the volume of saliva secreted per min. Viscosity, turbidity and foam determinations were determined immediately in order to avoid variations and subjectivity of a standardized observer, using a scale from + to +++ . Foam formed was observed as soon as saliva was placed in the tube Salivary turbidity was checked in the liquid collected, before ice-chilled, and viscosity was determined by the rupture of the mucus while taking the syringe off the tube. $\mathrm{pH}$ was also determined immediately using a Corning PS-30 pHmeter. Once saliva was collected, it was centrifuged at $5000 \mathrm{rpm}$ for $10 \mathrm{~min}$, fractionated and cooled down for protein determination. The remaining saliva was frozen for further analyses.

\section{Saliva Chemical Determinations}

Total proteins and $\alpha$-amylase were determined after collection in order to avoid daily variations caused by endogenous proteolytic activity.

Glucose determinations were performed using $100 \mu \mathrm{l}$ of saliva by the glucose-oxidase method. Total

Table 1. Mean and standard deviation of physical characteristics of saliva from diabetic and control children.

\begin{tabular}{|c|c|c|c|c|c|c|}
\hline & \multicolumn{3}{|c|}{ Diabetics $(n=20)$} & \multicolumn{3}{|c|}{ Non-Diabetics $(n=21)$} \\
\hline & Male $(n=9)$ & Female $(n=11)$ & Total & Male $(n=9)$ & Female $(n=12)$ & Total \\
\hline Flow rate $(\mathrm{ml} / \mathrm{min})$ & $0.15 \pm 0.09$ & $0.16 \pm 0.13$ & $0.15 \pm 0.11$ & $0.23 \pm 0.13$ & $0.27 \pm 0.14$ & $0.25 \pm 0.13$ \\
\hline $\mathrm{pH}$ & $6.81 \pm 0.51$ & $6.93 \pm 0.64$ & $6.89 \pm 0.58$ & $6.98 \pm 0.33$ & $7.16 \pm 0.27$ & $7.08 \pm 0.30$ \\
\hline Viscosity & ++ & ++ & ++ & + & $+/++$ & $+/++$ \\
\hline Turbidity & ++ & ++ & ++ & ++ & ++ & ++ \\
\hline Foam & $++/+++$ & $++/+++$ & $++/+++$ & ++ & $+/++$ & $+/++$ \\
\hline
\end{tabular}


sugars were determined by the Phenol Sulfuric method Total proteins were measured by the Biuret method with a minimum of $200 \mu 1$ of saliva. $\alpha$-amylase determinations needed $10 \mu \mathrm{l}$ of a $1 / 400$-fold saliva dilution. Acid phosphatase was determined by the colorimetric method, urea by the enzymatic method, and calcium was determined by the colorimetric complex. All reactions were performed using products from Sigma and Wiener Lab (Rosario, Argentina). No commercial kits for salivary determinations were available for the authors. Salivary determinations were performed in duplicate (except for $\alpha$-amylase that were done in triplicate). The technician was blinded to the dental history and the saliva source.

\section{Odontological Determinations}

The following indices were determined: DMFT (decayed, missing and filled permanent teeth), DMFS (decayed, missing and filled permanent surfaces), deft (decayed, extracted and filled deciduous teeth), defs (decayed, extracted and filled deciduous surfaces), GI (Gingival Index) (9) and PI (Plaque Index) (10). Dietary history (daily sweet uptake), DG (deep grooves) and WS (white spots) were also recorded by the same dentist.

\section{Statistical Analysis}

Statistical analysis considered interindividual variations. The BMDP computer program was used. The multivariate statistical Hottelling test was applied using the 3D program. The ANOVA test for each of the variables was applied, and the F statistics were calcu- lated in order to perform univariate descriptive statistics. The 7D and 7M programs were used for the individual and combined analyses. The discrimination analysis was performed by the $7 \mathrm{M}$ program, and the discrimination errors were analyzed in the Jackknifed classification matrix, constructed by the "leave-oneout" method (11). Linear regressions were carried out assuming a normal distribution of each parameter, and the correlation coefficients were determined.

\section{RESULTS}

\section{Physical and Chemical Determinations of Saliva}

Table 1 shows the mean \pm SD of flow rate, $\mathrm{pH}$, viscosity, turbidity, and foam for saliva of male and female diabetic and non-diabetic children. Flow rate diminished significantly in diabetic children as reported by other authors (1). Small sex differences were observed in both groups for $\mathrm{pH}$. It cannot be excluded that some of the differences observed between genders are due to differences in ages. Diabetic saliva was more viscous and had more foam than control saliva.

Biochemical determinations showed important differences between both groups of children (Table 2). Glucose, total sugars, total proteins and $\alpha$-amylase were greater in diabetic saliva, although the latter parameter showed a wide range of $\mathrm{SD}$, as reported previously (6). These parameters were inversely related to flow rate. Salivary glucose also had little correlation with glycemia and with glycosylated hemoglobin, $\mathrm{HbA1}$ (12).

Our results showed lower calcium values in diabetic saliva. Acid phosphatase had no statistical

Table 2. Mean and standard deviation of biochemical parameters of saliva from diabetic and control children.

\begin{tabular}{lccccccc}
\hline & \multicolumn{3}{c}{ Diabetics $(\mathrm{n}=20)$} & & & & Non-Diabetics $(\mathrm{n}=21)$ \\
\cline { 2 - 3 } & Male $(\mathrm{n}=9)$ & Female $(\mathrm{n}=11)$ & $\mathrm{x} \pm \mathrm{SD}$ & & Male $(\mathrm{n}=9)$ & Female $(\mathrm{n}=12)$ & $\mathrm{x} \pm \mathrm{SD}$ \\
\hline Glucose (mg/dl) & $1.95 \pm 1.48$ & $2.15 \pm 1.91$ & $2.05 \pm 1.63$ & & $1.55 \pm 1.57$ & $0.75 \pm 0.49$ & $1.03 \pm 1.03$ \\
Sugars (mg/dl) & $35.55 \pm 6.58$ & $35.32 \pm 13.47$ & $35.42 \pm 10.27$ & & $21.15 \pm 10.44$ & $21.30 \pm 10.26$ & $21.24 \pm 10.06$ \\
Urea (mg/dl) & $49.00 \pm 43.70$ & $45.25 \pm 29.43$ & $47.12 \pm 36.03$ & & $24.09 \pm 7.01$ & $27.02 \pm 13.67$ & $25.70 \pm 11.01$ \\
Calcium(mg/dl) & $3.06 \pm 0.99$ & $2.81 \pm 0.80$ & $2.93 \pm 0.88$ & & $3.44 \pm 0.84$ & $3.44 \pm 0.94$ & $3.44 \pm 0.89$ \\
Proteins (mg/dl) & $104.31 \pm 35.83$ & $115.57 \pm 41.38$ & $111.55 \pm 38.47$ & & $76.98 \pm 27.07$ & $84.15 \pm 35.96$ & $81.13 \pm 31.88$ \\
Amylase (AU/dl) & $46,648 \pm 17,693$ & $66,937 \pm 45,480$ & $58,822 \pm 37,412$ & $35,045 \pm 18,219$ & $35,808 \pm 16,781$ & $35,494 \pm 16,823$ \\
Acid Phosph. (IU/l) & $6.09 \pm 3.60$ & $4.85 \pm 2.92$ & $5.38 \pm 3.16$ & & $5.70 \pm 2.27$ & $6.34 \pm 4.12$ & $6.09 \pm 3.45$ \\
\hline
\end{tabular}


differences in both groups of children. Similar results were found for urea, except for three diabetic children whose individual values for urea were high. This fact caused the raising of the mean and the SD values. When salivary glucose and total proteins were related to flow rate no linear correlation was shown.

The multivariate method showed the statistical value $\mathrm{T} 2=31.983(\mathrm{p}=0.01)$ indicating that there were differences between the two groups. In order to determine the responsible parameters for these differences, a univariate descriptive test was applied. Flow rate, $\mathrm{pH}$ and the biochemical parameters were considered. Considering the individual parameters, the significance

Table 3. Mean and standard deviation of oral health observations of diabetic and control children.

\begin{tabular}{|c|c|c|}
\hline Indices & $\begin{array}{l}\text { Diabetics } \\
(n=20)\end{array}$ & $\begin{array}{l}\text { Non-Diabetics } \\
(n=21)\end{array}$ \\
\hline $\mathrm{D}$ & $4.07 \pm 4.25$ & $1.10 \pm 1.94$ \\
\hline M & $0.57 \pm 1.40$ & 0 \\
\hline $\mathrm{F}$ & $1.21 \pm 2.91$ & $0.85 \pm 1.56$ \\
\hline DMFT & $5.86 \pm 4.59$ & $1.95 \pm 2.37$ \\
\hline $\mathrm{D}$ & $6.28 \pm 7.94$ & $1.30 \pm 2.49$ \\
\hline M & $2.86 \pm 6.99$ & 0 \\
\hline $\mathrm{F}$ & $1.57 \pm 4.22$ & $1.05 \pm 1.99$ \\
\hline DMFS & $10.71 \pm 10.50$ & $2.35 \pm 3.03$ \\
\hline $\mathrm{d}$ & $2.17 \pm 2.21$ & $1.00 \pm 1.12$ \\
\hline $\mathrm{e}$ & $1.50 \pm 4.89$ & $0.33 \pm 0.84$ \\
\hline$f$ & $0.42 \pm 0.79$ & $0.83 \pm 1.25$ \\
\hline deft & $3.25 \pm 2.53$ & $2.17 \pm 2.09$ \\
\hline $\mathrm{d}$ & $3.25 \pm 3.60$ & $1.67 \pm 2.09$ \\
\hline e & $3.33 \pm 10.07$ & $1.67 \pm 4.20$ \\
\hline $\mathrm{f}$ & $0.42 \pm 0.79$ & $1.22 \pm 2.13$ \\
\hline defs & $7.00 \pm 9.85$ & $4.55 \pm 5.38$ \\
\hline DMFT-deft & $9.11 \pm 7.12$ & $4.12 \pm 4.46$ \\
\hline DMFS-defs & $17.71 \pm 20.35$ & $6.90 \pm 8.41$ \\
\hline Plaque Index & $0.55 \pm 0.21$ & $0.28 \pm 0.28$ \\
\hline Gingival Index & $0.48 \pm 0.25$ & $0.23 \pm 0.23$ \\
\hline Dietary History & $0.30 \pm 0.47$ & $6.76 \pm 1.34$ \\
\hline Deep Grooves & $0.81 \pm 1.12$ & $0.30 \pm 0.57$ \\
\hline White Spots & $0.43 \pm 0.98$ & $0.20 \pm 0.52$ \\
\hline
\end{tabular}

DMFT: decayed, missing, filled permanent teeth DMFS: decayed, missing, filled permanent teeth surfaces deft: decayed, extracted, filled deciduous teeth defs: decayed, extracted filled deciduous teeth surfaces order was total sugars, proteins, urea, calcium and glucose. In the combined analysis the order was calcium, urea, total sugars, proteins and $\alpha$-amylase. From these results, five parameters were selected and analyzed together. The order of these parameters was total sugars, calcium, urea, glucose and total proteins.

Furthermore, a discrimination analysis was performed in order to determine the probability $(0.5 \%$, the program default) that each child would be well classified as diabetic or non-diabetic. The five parameters mentioned above were considered. The percentage of correct classification for the diabetic group was $90.9 \%$, and $88.2 \%$ for the control group, i.e. one child considered as diabetic should have been classified as control, and two controls could be diabetic. The total percentage of correct diagnosis was 89.3 , i.e. there was a probability of nearly $90 \%$ that a diabetic child was diagnosed correctly through these salivary parameters.

\section{Odontological Determinations}

Table 3 shows the odontological indices for both groups. Even though diabetic and non-diabetic children were of similar age, in the first group $40 \%(n=8)$ of the children had permanent dentition, $30 \%(n=6)$ deciduous, and $30 \%(\mathrm{n}=6)$ mixed dentition. In the control group, the majority had mixed dentition $(81 \%, \mathrm{n}=17)$, only $14.3 \%(n=3)$ permanent and $4.7 \%(n=1)$ deciduous dentition. Average values were calculated for present teeth.

The oral health state of diabetic children was not as good as control children in terms of DMFT, DMFS, deft and defs indices. Statistically significant differences were also observed for PI, WS, GI and DG, which indicates the need of applying added preventive measures with diabetic patients (Table 3).

\section{DISCUSSION}

In this study, biochemical aspects of the saliva and the oral health observed were compared between pre-pubertal and mid-pubertal children with diabetes mellitus and a control group with similar characteristics. As recommended previously (12), HbAland microalbuminuria was measured the day of saliva collection.

Whole saliva was unstimulated on collection. Flow rate, which was significantly diminished $(\mathrm{p}<0.001)$ 
in diabetics, was associated to salivary viscosity and foam. Viscosity (also called "spinbarkeit" by Jenkins (6)) and foam are reflected by the higher level of proteins in diabetic patients, and salivary turbidity is related to mucus, epithelial cells and especially to oral bacteria presence (4). There is much research relating diminished flow rate to diabetes in adults and children, as if the overall dehydration could cause irreversible changes of the glands (13).

Our findings that control males had lower secretion rates than females are not in agreement with the results reported for adults by Percival et al. (14) who reported higher levels of unstimulated whole saliva in males. They explained these results on the basis of female salivary glands being smaller than those of males, and probably also due to a loss of estrogen of post-menopausal women.

The acid $\mathrm{pH}$ in diabetic children may be associated either to microbial activity or to a decrease of bicarbonate with flow rate.

Salivary chemical contents also showed some differences between groups. Glucose was not correlated with glycemia or HbA1 (12), although diabetic saliva values were higher than in controls. These results are in agreement with those of Karjalainen et al. (13), who reported that salivary glucose level decreased after beginning insulin treatment in both children and adolescents.

Salivary glands act as filters of blood glucose that would be altered by hormonal or neural regulation (15). These diabetic children also showed negative urinary protein levels (12). Consequently, further studies are necessary to determine if high glycemia values could alter salivary filtration capacity as renal filtration capacity does.

Salivary glucose has no linear correlation with PI and GI, although these two are correlated (12). Total sugar values were also higher in saliva from diabetics than in controls. However, they were not correlated to caries-related indices in the current study (data not shown).

Other chemical salivary determinations in diabetic children are quite different from those of the nondiabetic group. Total proteins and $\alpha$-amylase were slightly lower than those for diabetic adults reported by Yavuzyilmaz et al. (16). However, both salivary values were higher in the diabetic group than in controls. These differences may be caused by stress (15), even though stress situations were avoided in this study. $\alpha$ amylase showed a great variation in terms of the $\mathrm{SD}$, as reported previously by Jenkins (6).

Calcium, total proteins and $\alpha$-amylase determined for non-diabetics were similar to those reported for adult normal saliva using different methods than those used in this study (17). Compared to the results of Jenkins (6), our results from control children for calcium, urea and glucose were similar, but those for proteins and $\alpha$-amylase were lower. Dodds and Dodds (18) associated elevated amylase activity with taste alterations in poorly controlled non-insulin-dependent diabetes mellitus adults.

In normal saliva, calcium-phosphate precipitation is inhibited by specific salivary proteins that bind calcium (19). In our results obtained from diabetic children, protein salivary values were increased probably due to greater microorganism activity, or they could perhaps be proteins of periodontal tissue origin.

Urea may physiologically maintain salivary $\mathrm{pH}$ close to normality. Acid phosphatase as a component of parotid saliva was similar in diabetic and control children.

Using total sugars, calcium, urea, glucose and total proteins for discrimination analysis, almost $90 \%$ of the children in this study were well characterized as diabetic or non-diabetic. It should be taken into consideration that they are children under insulin treatment.

There was no relation of salivary determinations with caries; however, oral health of diabetic patients was deficient compared to controls. Collin et al. (20) found no association between diabetes and prevalence of caries in diabetic adults. However, cooperation between the diabetologist and the dentist is needed.

Total saliva is a fluid of easy collection that could help diagnosis or monitoring systemic illness, such as diabetes. In this paper it is shown that some salivary biochemical parameters are statistically different and could be considered when classifying a child as diabetic. It is also demonstrated that saliva composition may correspond to the systemic state of the patient rather than the oral health state.

\section{ACKNOWLEDGMENTS}

This work was partially supported by a grant from CIUNT (Consejo de Investigaciones de la Universidad Nacional de Tucumán). The authors wish 
to thank Dr. Cristina Bazán, Director of the Endocrinology Service of Niño Jesús Hospital where saliva collection was performed, and Lic. Fabián E. Pacheco and Lic. Stella M. Vaira for statistical processing data at the INIE (Instituto Nacional de Investigaciones Estadísticas) of the Facultad de Ciencias Económicas, UNT.

\section{RESUMO}

Os componentes salivares podem sofrer variações que podem ser detectadas por análise química. $\mathrm{O}$ objetivo desse trabalho foi determinar as características físicas e bioquímicas da saliva de um grupo de crianças diabéticas comparadas a um grupo controle. A relação com a saúde oral também foi determinada. Vinte crianças diabéticas (3-15 anos) e 21 crianças do grupo controle (5-12 anos) foram incluídas nesse estudo. Quantidade total de proteínas, açúcares e cálcio foram determinadas por métodos colorimétricos e glicose, uréia, $\alpha$-amilase e ácido fosfórico por métodos enzimáticos. Nossos resultados demonstraram que o $\mathrm{pH}$ ácido diminuiu o fluxo salivar e o excesso de espuma são normalmente encontrados na saliva de crianças diabéticas. $\mathrm{O}$ total de açúcares, glucose, uréia e proteínas foram maiores em pacientes diabéticos do que no controle enquanto o cálcio diminuiu. Essas diferenças foram confirmadas pelo teste de discriminação. As crianças diabéticas têm maiores valores de DMFT-dmft-deft and DMFS-dmfs-defs quando comparadas àquelas do grupo controle apesar do menor consumo de açúcar. Alguns componentes salivares e a diminuição do fluxo salivar podem estar envolvidos na caracterização da saúde oral das crianças diabéticas.

\section{REFERENCES}

1. Thorstensson H, Falk H, Hugoson A, Olsson J. Some salivary factors in insulin-dependent diabetics. Acta Odontol Scand 1989;47:175-183.

2. Emrich LH, Sholassman M, Genco RJ. Periodontal disease in non insulin-dependent diabetes mellitus. J Periodontol 1991;62:123130.

3. Karjalainen KM, Knuuttila MLE, Käär ML. Relationship between caries and level of metabolic balance in children and adolescents with insulin-dependent diabetes mellitus. Caries Res 1997;31:13-18.

4. Yalda B, Offenbacher S, Collins JG. Diabetes as a modifier of periodontal disease expression. Periodontol 2000 1994;6:37-49.
5. Tukia-Kumala H, Tenovuo J. Intra and inter individual variation in salivary flow rate, buffer effect, lactobacilli, and mutans streptococci among 11- to 12-year-old school children. Acta Odontol Scand 1993;51:31-37.

6. Jenkins GN. Saliva. In: Fisiología y Bioquímica Bucal. Limusa ed. 4th ed. México: 1983. p 284-360.

7. Harrison R, Bowen WH. Flow rate and organic constituents of whole saliva in insulin-dependent diabetic children and adolescents. Pediatr Dent 1987;9:287-291.

8. Sharon A, Ben Aryed H, Itzhak B, Yoram K, Szargel R, Gutman D. Salivary composition in diabetic patients. J Oral Med 1985;40:23-26.

9. Löe H, Silness J. Periodontal disease in pregnancy (I). Prevalence and severity. Acta Odontol Scand 1963;21:551-553.

10. Silness J, Löe H. Periodontal disease in pregnancy (II). Correlation between oral hygiene and periodontal condition. Acta Odontol Scand 1964;24:747-759.

11. Morrison DF. Classification by the linear discriminant function. In: Multivariate statistical methods. Blackwell D, Solomon H. eds. 2nd ed. New York: McGraw-Hill Book Company; 1993. p 230-264.

12. López ME, Páez RG, Abarracín M, Granito S, Chervonagura A, Bazán C. Evaluación clínica de niños diabéticos relacionada al estado de salud bucal. Acta Odont Venezol 1998;36:13-18.

13. Karjalainen KM, Knuuttila ML, Käär ML. Salivary factors in children and adolescents with insulin-dependent diabetes mellitus. Pediatr Dent 1996;18:306-311.

14. Percival RS, Challacombe SJ, Marsh PD. Flow rates of resting whole and stimulated parotid saliva in relation to age and gender. J Dent Res 1994;73:1416-1420.

15. Chatterton Jr RT, Vogelsong KM, Lu YC, Ellman AB, Hudgens GA. Salivary alpha-amylase as a measure of endogenous adrenergic activity. Clin Physiol 1996;16:433-448.

16. Yavuzyilmaz E, Yumak O, Akdoganli T, Yamalik N, Ozer N, Ersoy F, Yeniay I. The alterations of whole saliva constituents in patients with diabetes mellitus. Aust Dent J 1996;41:193-197.

17. Lenander-Lumikari M, Johansson I, Vilja P, Samaranayake LP Newer saliva collection methods and saliva composition: a study of two Salivette kits. Oral Dis 1995;1:86-91.

18. Dodds MWJ, Dodds BDS. Effects of glycemic control on saliva flow rates and protein composition in non-insulin-dependent diabetes mellitus. Oral Surg Oral Med Oral Pathol Oral Radiol Endod 1997;83:465-470.

19. Hay DI. Salivary factors in caries models. Adv Dent Res 1995;9:239-243.

20. Collin HL, Uusitupa M, Niskanen L, Koivisto AM, Markkanen H, Meurman JH. Caries in patients with non-insulin dependent diabetes mellitus. Oral Surg Oral Med Oral Pathol Oral Radiol Endod 1998;85:680-685. 